\title{
オーステナイトステンレス鋼溶接部の機械的性質に及ぼす 超音波振動の影響*
}

\author{
渡辺 健彦**, 大河原修平***, 関 伸介 ${ }^{* * *}$, 柳沢 敦**, 小沼 静代 **
}

\begin{abstract}
The Effect of Ultrasonic Vibration on The Mechanical Properties of Austenitic Stainless Steel Weld*
\end{abstract}
by WATANABE Takehiko**, OOKAWARA Shuuhei***, SEKI Shinsuke***,

YANAGISAWA Atsushi** and KONUMA Shizuyo**

\begin{abstract}
This study was carried out to clarify whether it is possible or not to improve the mechanical properties of welds by means of applying ultrasonic vibration to the weld metal. Autogenous weld by TIG process was made on an austenitic stainless steel plate vibrated ultrasonically. The effects of the ultrasonic vibration on the solidification structure and the mechanical properties of the weld were examined. The main results obtained in this study are as follows.

The ultrasonic vibration applied to the weld metal makes the tensile strength of the weld higher than that of the conventional weld. By the ultrasonic vibration, the width of an austenite columnar crystal in the weld metal is decreased and this is likely to be one of the factors to increase the tensile strength of the weld.

The ultrasonic vibration changes the microstructure in the weld metal from cellular dendrite morphology in non-vibrated weld metal to subgrain morphology aligned in the growth direction. The existence of the subgrain boundary is also likely to be one of the factors to increase the tensile strength of the weld.

The ultrasonic vibration decreased the primary dendrite arm spacing in the weld metal, causing the weld strength to increase. The larger the ultrasonic vibration amplitude is, the more conspicuous the above phenomena are.
\end{abstract}

Key Words: Ultrasonic vibration, Tensile strength of weld, Solidification structure, Width of columnar crystal, Subgrain boundary, Primary dendrite arm spacing

\section{1. 緒言}

アーク溶接部のような溶融溶接部は溶接金属部と熱影響 部で構成されており, それらの組織は母材のそれとは異 なっている。一般に, 溶接金属は熱影響部からのエピタキ シャル成長に起因した集合組織を形成して粗大な結晶とな る.このため, 溶接金属部の機械的性質は母材に比して劣 る傾向にあり, 溶接入熱の増加とともに引張強さや耐力は 低下することが知られている ${ }^{1)}$.

さて, 鋳造材の材質改善を目的に, 鋳型内の溶湯に振動 や擋汼を与えて鋳塊の凝固組織を微細化する研究が多数行 われている ${ }^{2) ~ 7)}$ 。一方, 溶接金属の凝固は小型の連続的な 鋳造現象にほかならない. したがって, 溶接金属にも振動 などの外乱を与えることによって, 結晶粒の微細化や機械 的性質の向上が期待できる。このような観点から，アルミ ニウム合金溶接金属 ${ }^{8)}$, 9) やオーステナイトステンレス鋼溶

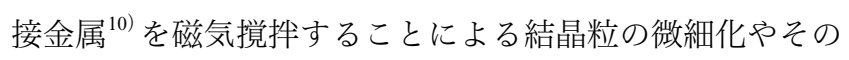

\footnotetext{
*原稿受付 平成 14 年 7 月 24 日 平成 10 年度秋季全国大会 で発表

**正 員 新潟大学工学部 Faculty of Engineering, Niigata University

***学生員新潟大学大学院 Graduate School, Niigata University
}

効果を調べた研究はあるが, 溶接金属に超音波振動を与え た場合の影響を調べた研究は見あたらない.

そこで, 本研究では, オーステナイトステンレス鋼板に 超音波振動を与えながらティグによるビードオンプレート 溶接を行い，溶接部の機械的性質や溶接金属の凝固組織に およぼす超音波振動の影響について基礎的な検討を行った.

なお, 被溶接板全体を超音波によって振動させることは, 実施工上はほぼ不可能ではあるが, 本研究では超音波振動 の影響を学術的に調べることを目的に行った。

\section{2. 実 験 方 法}

\section{1 供試材}

供試材には, 凝固組織の観察を容易にするために, 冷却 途上で変態を生じない市販の板厚 $1 \mathrm{~mm}$ のオーステナイトス テンレス鋼板 SUS3 $310 \mathrm{~S}(\mathrm{Fe}-0.04 \% \mathrm{C}-0.42 \% \mathrm{Si}-0.36 \%$ $\mathrm{Mn}-0.016 \% \mathrm{P}-0.001 \% \mathrm{~S}-24.81 \% \mathrm{Cr}-20.24 \% \mathrm{Ni}$ (mass \%)）を用いた。

供試材からFig. 1に示すような形状・寸法の溶接用試験片 を切り出した. 試験片を超音波振動付加用のステップホー ンに取り付けるために, 試験片の端部から $10 \mathrm{~mm}$ の位置に 直径 $5 \mathrm{~mm}$ の穴をあけた。 


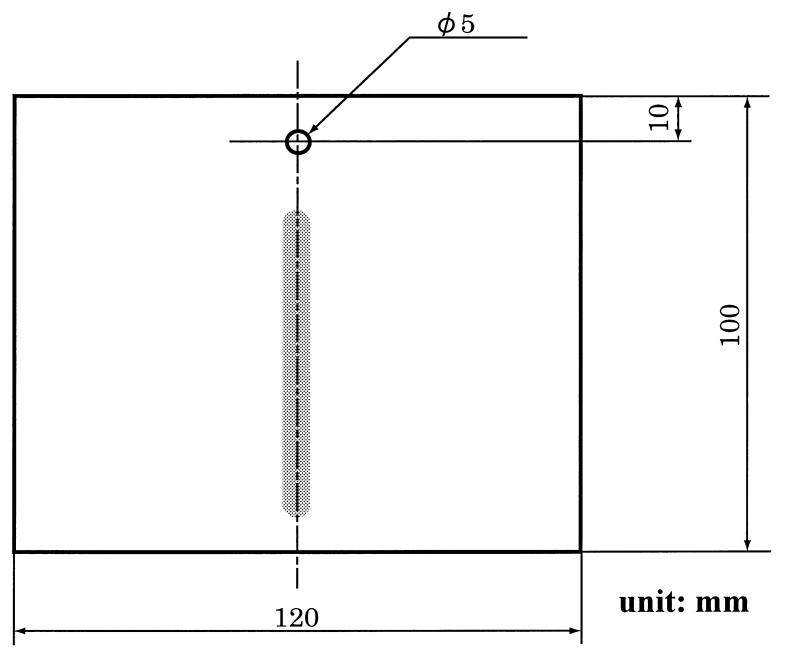

Fig. 1 Shape and size of a test plate for autogenous weld

\section{2 超音波振動の付加方法と溶接方法}

Fig. 2 に示すように, 出力 $600 \mathrm{~W}$, 周波数 $19 \mathrm{kHz}$ で振動 している振動子に連結されているステップホーンに Fig. 1 に示した試験片をボルトとナットで取り付けて超音波振動 を付与した。

溶接はティグによるビードオンプレート溶接とし, Fig. 1 に示した試験片の中央の影部にビードを置いた。溶接速度 は $1.67 \mathrm{~mm} / \mathrm{s}, 3.33 \mathrm{~mm} / \mathrm{s}$ 抢よ゙゙ $6.67 \mathrm{~mm} / \mathrm{s}$ の三段階とした。

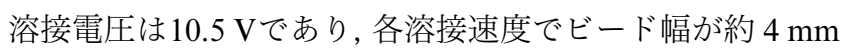
になるように電流を調節した。シールドガスは $99.999 \% の$ 高純度アルゴンを使用し, 試験片表面および裏面をシール ドした。 ガス流量は, 表面側は $0.25 \mathrm{~L} / \mathrm{s}$ で裏面側は $0.17 \mathrm{~L} / \mathrm{s}$ とした。溶接は超音波振動を付加した場合と付加しない場 合について行った.

\section{3 超音波振動振幅の設定}

試験片に超音波振動を付加した際の振動の腹と節の分布 を調べるために, 試験片上にセラミックス粉末を振り撒い た時に現れる模様をFig. 3に示す. 白く見える箇所が振動の 節の位置である。板のほぼ中央部に存在する Aで示した領 域が振動の腹に対応するので, 図に示すようにホーンの先 端から $40 \mathrm{~mm}$ の位置に抢ける振幅を光学顕微鏡で測定した。 この位置における振幅（ピークからピークの值）を $5.0 \mu \mathrm{m}$ になるように設定して，溶接部の機械的性質や溶接金属の 凝固組織に及ぼす影響を調べた。

また，振幅の大きさの影響を調べる場合には，振幅を 2.1 $\mu \mathrm{m}, 4.3 \mu \mathrm{m}, 5.3 \mu \mathrm{m}, 7.5 \mu \mathrm{m}$ と変化させた.

\section{4 溶接部の評価}

溶接部の引張強さを測定するための引張試験片の形状と 寸法はFig. 4に示すようであり, 引張試験片の中央部が溶接 板の振動腹部と一致するょうに切り出した。引張試験片の

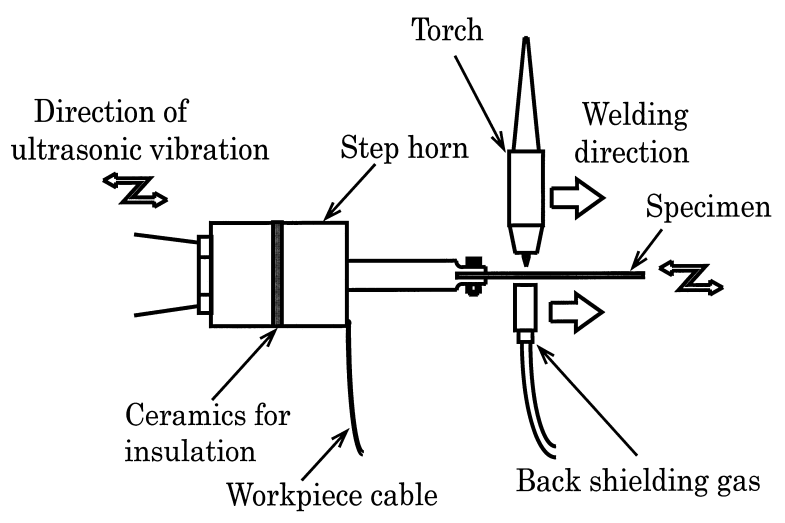

Fig. 2 Schematic representation of an apparatus for welding with ultrasonic vibration

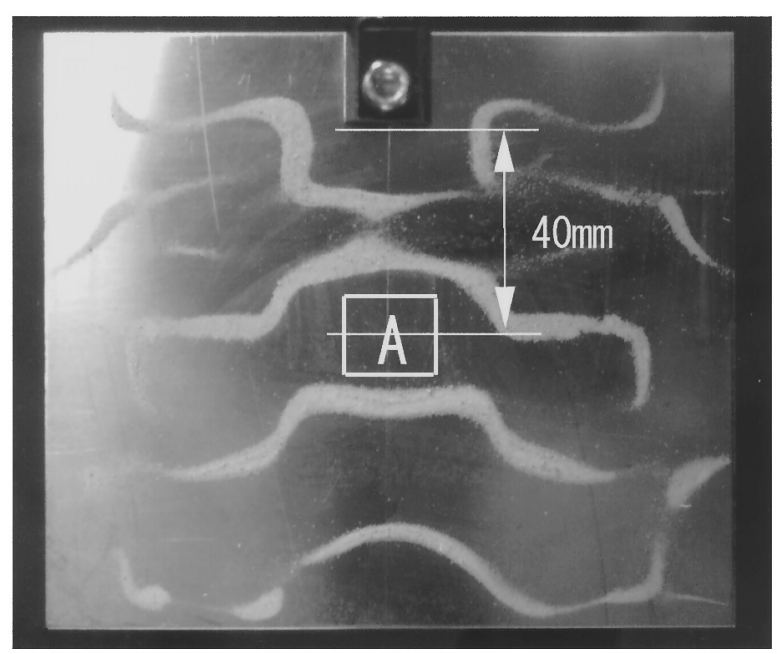

Fig. 3 Photograph showing the positions of vibration node and loop on a plate. White-looking bands are corresponding to the vibration node. Part of A is corresponding to the vibration loop.
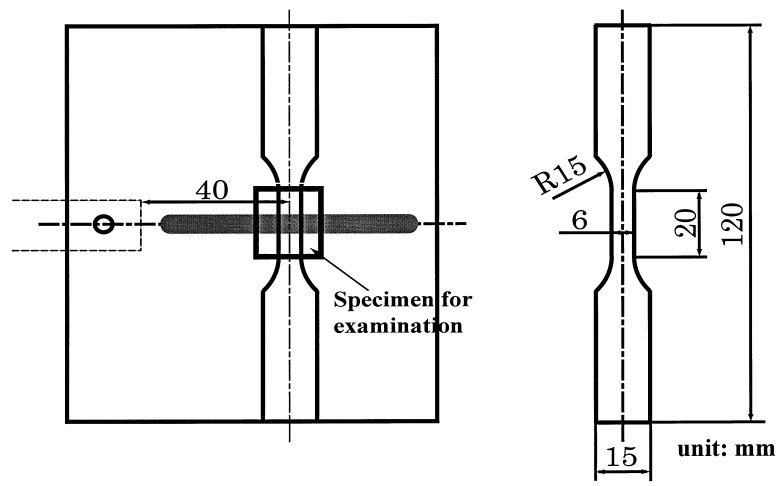

Fig. 4 Schematic illustration showing the positions from which the specimens for various examinations were machined.

平行部は，溶接金属部の表面と裏面の凹凸を取り除くため にエメリー紙研磨を施しており, 厚さは約 $0.9 \mathrm{~mm}$ である。 引張速度は $1 \mathrm{~mm} / \mathrm{min}$ とした。

また，凝固組織の観察や方位解析および結晶粒の大きさ 
測定用の試片 $(15 \times 10 \mathrm{~mm})$ も Fig. 4 に示すように溶接板 の振動腹部から切り出した。凝固組織の現出は, 鏡面研磨 後 $10 \%$ シュウ酸水溶液中での電解腐食によった。溶接金属 部のオーステナイト結晶粒は熱影響部からエピタキシャル に柱状に成長していることから, 柱状晶の幅をリニアイン ターセプト法で測定して，それをオーステナイト結晶粒の 大きさの代用とした.

測定の手順は次のようである。最初に，鏡面研磨を施し た試片を高温酸化し ${ }^{11)}$ 室温オーステナイト粒界を現出し た。これを倍率 $\times 20$ で撮影した写真上に溶接線と平行に $5 \mathrm{~mm}$ 間隔で $50 \mathrm{~mm}$ 長の線分を引き，この線分と室温オー ステナイト粒界との交点数で線分長を除して柱状晶の幅を 求めた。

\section{3. 実験結果および考察}

\section{1 溶接部の引張強さ}

振幅5.0 $\mu \mathrm{m}$ の超音波振動を付加した場合としない場合に ついて, 溶接速度を三段階に変えて溶接を行い溶接部の引 張強さを調べた。その結果を Fig. 5 に示す.

超音波振動の付加の有無にかかわらず溶接部の引張強さ は母材のそれよりも小さく，破断はいずれの溶接速度の場 合も溶接金属部で生じていた. Fig. 6は高温酸化して現出し た溶接金属部の室温オーステナイト粒界をトレースした図 である。右側の図が超音波振動を付加した場合である。溶 接速度が $1.67 \mathrm{~mm} / \mathrm{s}, \quad 3.33 \mathrm{~mm} / \mathrm{s}$ と $6.67 \mathrm{~mm} / \mathrm{s}$ の場合につい て Fig. 6の（a）（c) にそれぞれ示す.いずれの場合も, 溶 接金属部の結晶粒は母材のそれよりもかなり大きくなって おり，このために溶接部の引張強さが小さくなったと思わ れる。なお，母材の結晶粒は，Fig. 6 (a) の右の図の両端 に小さく見られる.

次に，超音波振動を付加しない場合，溶接速度が大きく なると溶接部の引張強さは小さくなるが，この理由は以下 のようである. Fig. 6の柱状晶の粒界トレース図からも分か るように，溶接速度が大きくなると熱影響部から成長する

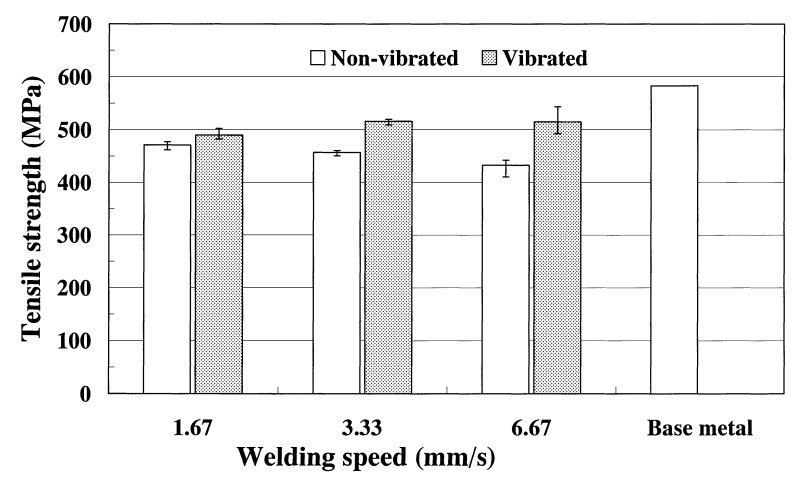

Fig. 5 The effect of ultrasonic vibration on the tensile strength of welds performed at various welding speeds.
柱状晶の成長方位が溶接線に対して垂直に近づき，いわゆ る，引張試験の引張方向と平行になりやすくなる ${ }^{12)}$.すな わち，溶接金属内の $\langle 100\rangle$ 成長方位をもつ柱状晶の成長方 向と引張方向とが一致する確率が高くなり，溶接金属部の 塑性変形が生じやすくなって引張強さが低下するためであ る.この点についての詳細な検討はすでに報告している ${ }^{13)}$. 次に, 超音波振動を付加した溶接部の引張強さはFig. 5に 示したように，いずれの溶接速度においても超音波振動を 付加しない場合よりも向上しており, 溶接速度が $3.33 \mathrm{~mm} / \mathrm{s}$ と $6.67 \mathrm{~mm} / \mathrm{s}$ の場合には約 $12 \%$ 向上した.

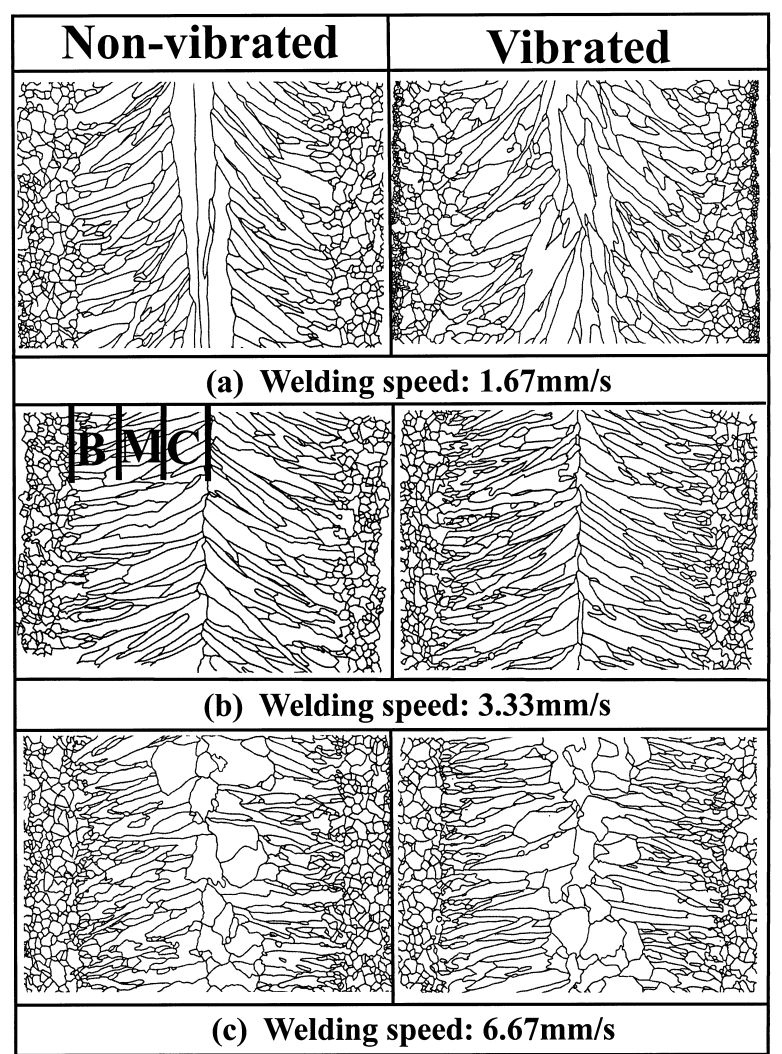

Fig. 6 The traces of room temperature grain boundary in the weld metals with ultrasonic vibration and no vibration.

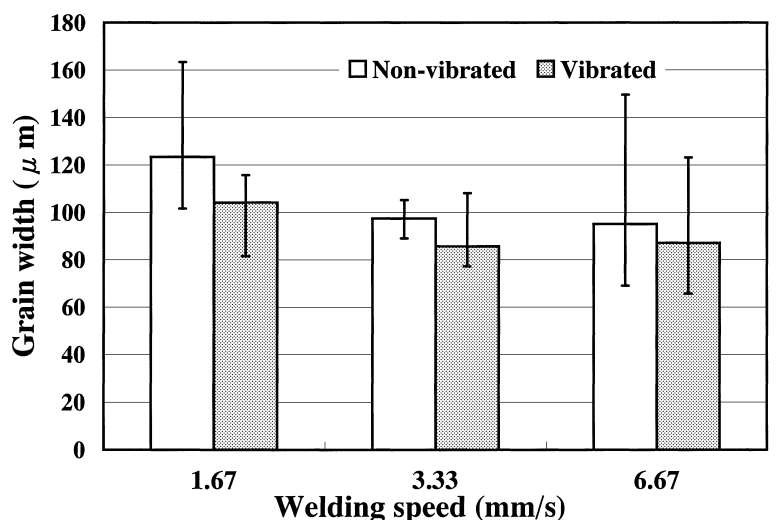

Fig. 7 The effect of ultrasonic vibration on the columnar grain width in weld metal made at various welding speeds. 
金属材料の結晶粒が大きくなるとその降伏強さが小さく

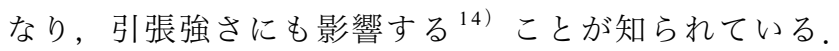
Fig. 6 に示したオーステナイト結晶粒のトレース図を用い て, 溶接速度を変化させて超音波振動を付加した場合とし ない場合の溶接金属部の柱状オーステナイト粒の幅の変化 をリニアインターセプト法によって測定した結果を Fig. 7 に示す.

超音波振動を付加することによって柱状晶幅が減少して おり，オーステナイト結晶粒が小さくなることが溶接部の 引張強さが向上した一因と考えられる。

\section{2 超音波振動付加による凝固組織の変化}

超音波振動を付加した場合および付加しない場合の溶接 金属凝固組織を Fig. 8 に示す。(a)〜 (c) は，それぞれ溶接 速度が $1.67 \mathrm{~mm} / \mathrm{s}, 3.33 \mathrm{~mm} / \mathrm{s}$ と $6.67 \mathrm{~mm} / \mathrm{s}$ の場合である。い ずれも Fig. 6 (b) 中に示した M 領域の凝固組織であり, 試 料面に垂直および柱状晶の成長方向と直角の断面組織であ る. 左側の写真が超音波振動を付加しない場合, 右側の写 真が超音波振動を付加した場合の凝固組織である.

試料面に垂直の凝固組織をみると, 超音波振動を付加す ることによっていずれの溶接速度においてもセルラーデン ドライトがセル化しており, 明らかな凝固組織の変化が観 察される。

セル化した小結晶の方位（試料面法線方位）を ECP 法 ${ }^{15}$ によって調べた. その結果を Fig. 9 に示す. 超音波振動の付 加時と無付加時の場合の結果を示した。 Fig. 9（a）は溶接 速度 $1.67 \mathrm{~mm} / \mathrm{s}$ の結果である. 超音波振動を付加しない場合 は成長方向に延びたセルラーデンドライト内での結晶方位 差は当然の事であるが見られない（○印）。一方，超音波振 動を付加した場合には, 成長方向にセル状結晶が連なって

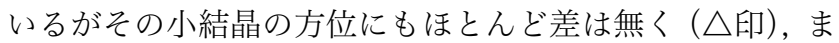
た，隣接するセル状結晶間にも方位差はほとんど見られな い( $\mathbf{\Delta}$ 印).

しかし，Fig. 9（b）および（c）に示すように，溶接速度 が $3.33 \mathrm{~mm} / \mathrm{s}$ および $6.67 \mathrm{~mm} / \mathrm{s}$ になると, 超音波振動を付加 した場合には成長方向に連なっているセル状結晶の方位が 少し異なっており，サブグレイン状になっていることが分 かる。また，隣接するセル状晶間にも若干の方位差がみら れる。

そこで，成長方向に連なっているサブグレイン状結晶間 の方位差 (Misorientation angle) をRandle ${ }^{16)}$ にる方法 で計算した。

すなわち，各サブグレイン状結晶の試料表面法線方位は $3 \times 3$ マトリックスで表され, 例えば $\mathrm{A}$ 結晶および $\mathrm{B}$ 結晶の 試料面法線方位を表すマトリックスをそれぞれ A および B とする. B 結晶の方位を A 結晶の方位に変換するマトリッ クスを $\mathrm{M}$ とすると, $\mathrm{M}=\mathrm{A} \times \mathrm{B}^{-1}$ となり， $\mathrm{M}$ が二結晶の 相対方位関係を表す回転マトリックスとなる。回転マト リックス $\mathrm{M}$ の固有ベクトルが回転軸に対応しており，その 回転軸と回転角 $\theta$ を計算した。

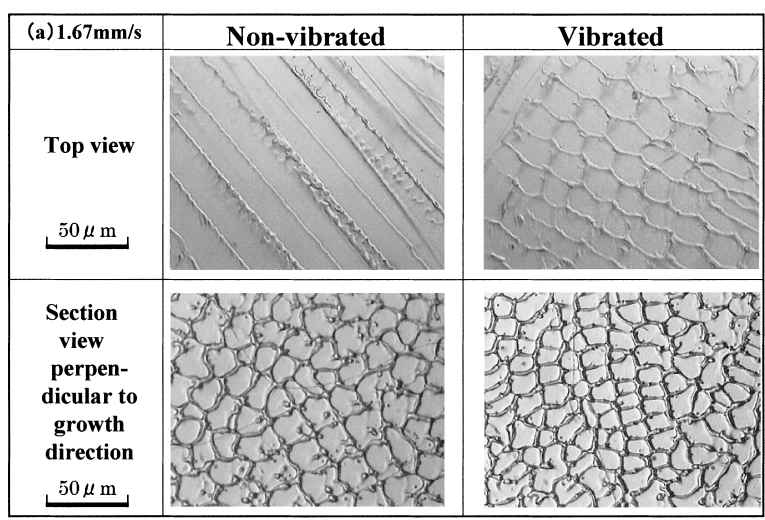

(a)

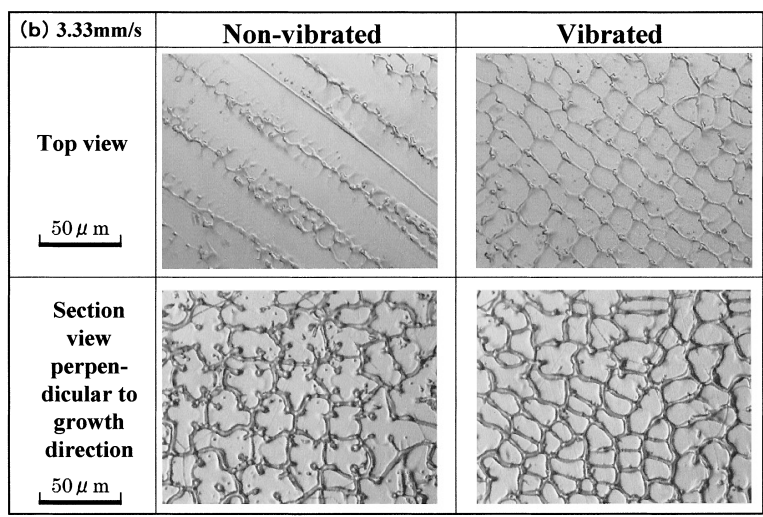

(b)

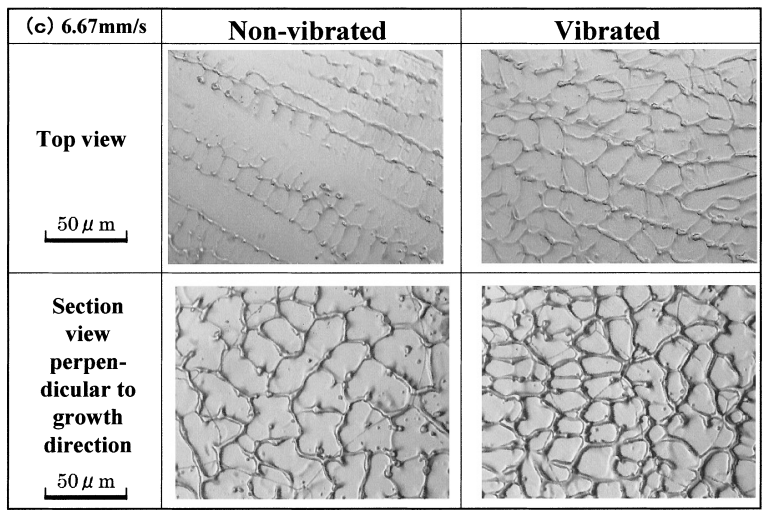

(c)

Fig. 8 Microphotographs of top view and section view of weld metals made with ultrasonic vibration and no vibration.

なお，隣接する二結晶の相対方位間の回転角 $\theta$ が約 15 度 以上になると，小角度粒界から高角度粒界になることが知 られている ${ }^{17)}$.

ここでは，この回転角を結晶間の方位差として計算した 結果を Fig. 10 に示す. 溶接速度が大きくなるにつれてサブ グレイン状結晶間の方位差は大きくなるが，いずれも 1 度 以下である。したがって，Fig. 8 およびFig. 9 に見られるサ ブグレイン状の結晶粒界は小角度粒界とみなされ，成長方 向に連なった小結晶はサブグレインであると判定される. 

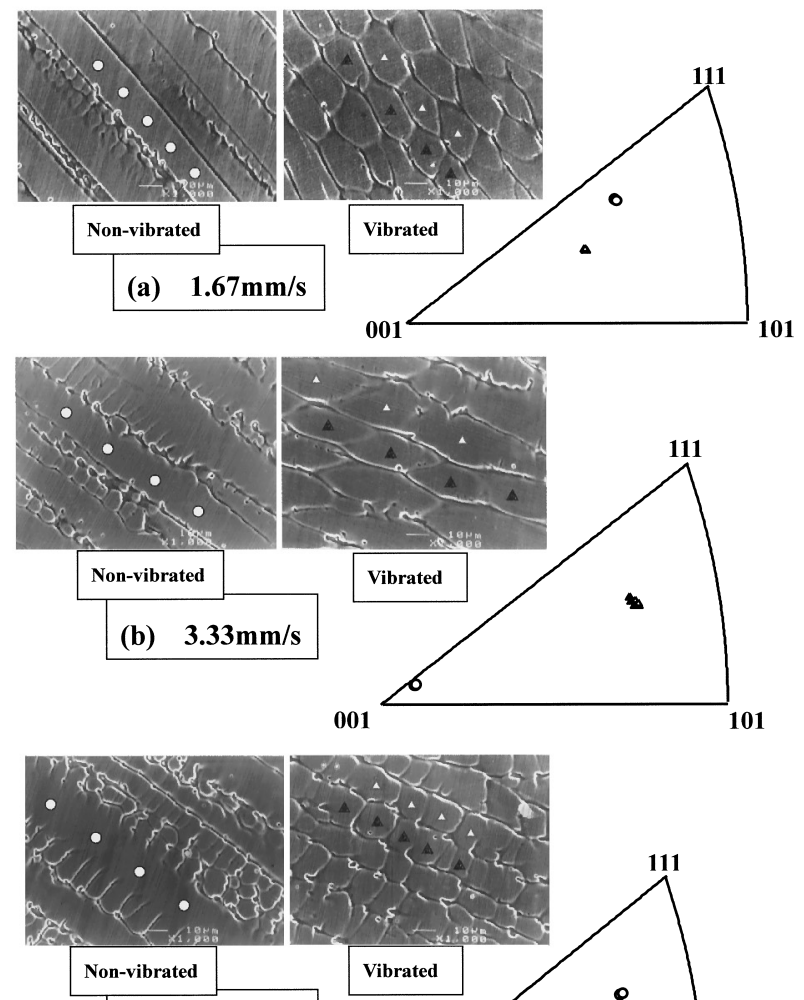

(c) $6.67 \mathrm{~mm} / \mathrm{s}$

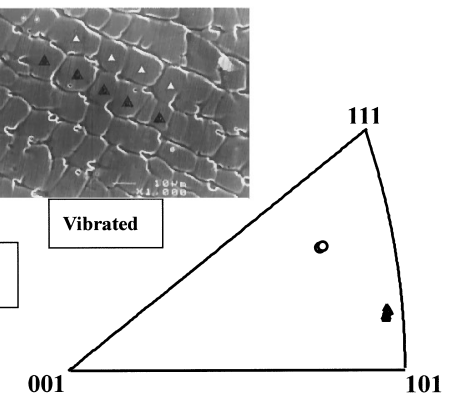

Fig. 9 Stereographically projected orientations of crystals in weld metal performed with ultrasonic vibration and no vibration.

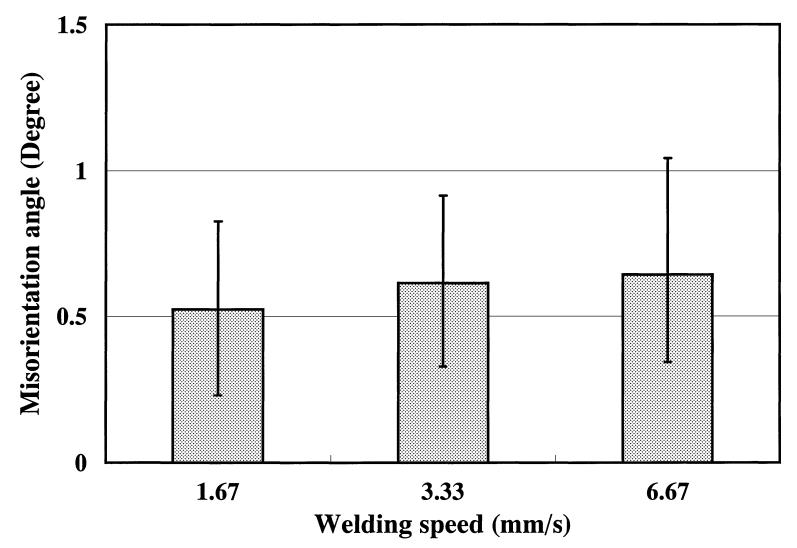

Fig. 10 Comparison of the misorientation angle of the grains in weld metal with ultrasonic vibration to those in weld metal without vibration

次に，成長方向と直角に切った $\mathrm{M}$ 領域の断面凝固組織を Fig. 8 に示したが, Fig. 6 (b) 中に示す B 領域, M 領域お よび C 領域の断面凝固組織を溶接速度が $3.33 \mathrm{~mm} / \mathrm{s}$ の場合 について Fig. 11 に示す。下段が超音波振動を付加した場合 である。

超音波振動を付加することによって, 各領域の Primary

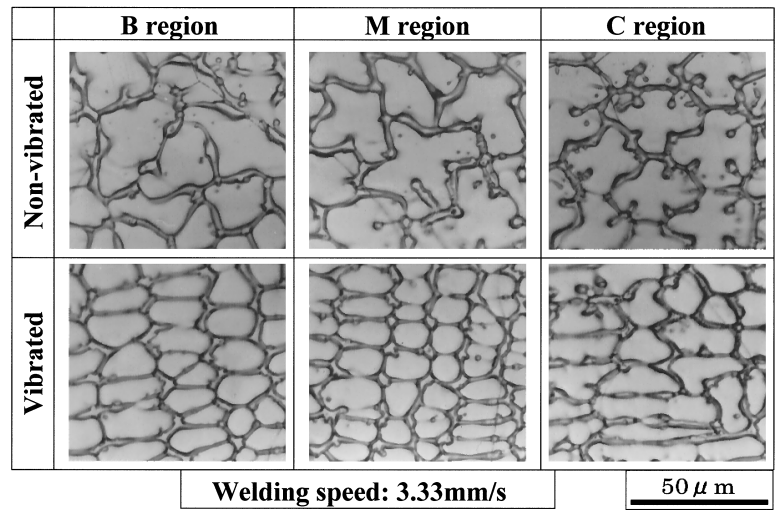

Fig. 11 Sectional views of columnar grain perpendicular to the growth direction in weld metal made with ultrasonic vibration and no vibration.

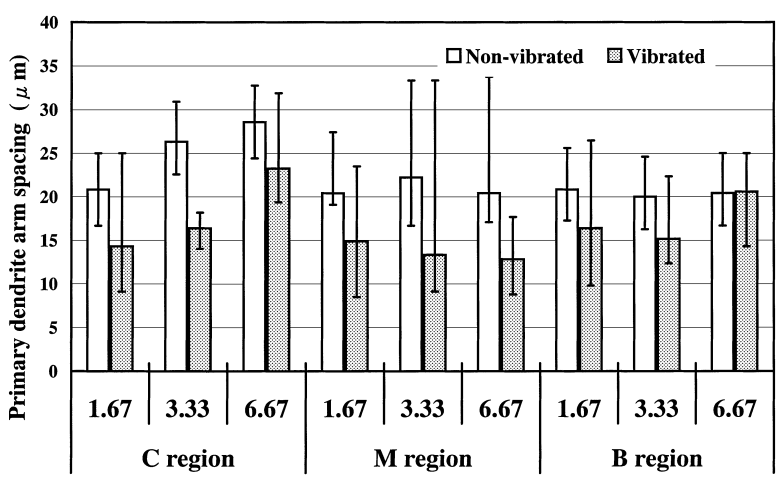

Fig. 12 The change in primary dendrite arm spacing in the regions of $\mathrm{C}, \mathrm{M}$ and $\mathrm{B}$ in weld metal when ultrasonic vibration is applied or not.

Dendrite Armの断面の大きさが明らかに小さくなっている ことが分かる。溶接速度が $1.67 \mathrm{~mm} / \mathrm{s}$ と $6.67 \mathrm{~mm} / \mathrm{s}$ の場合も 同様の傾向であった。

B，C，D領域における Primary Dendrite Arm の中心の間 隔の平均值と溶接速度と超音波振動付加の有無との関係を Fig. 12に示す.超音波振動を付加することによって, Primary Dendrite Arm中心の間隔がいずれの溶接速度及びいずれの 領域においても小さくなっており, つまり, Primary Dendrite Armの断面の大きさが小さくなっていることがわかる.

\section{4. 超音波振動付加による溶接部の引張強さ向上の 要因について}

Fig. 5 に示したように，溶接時に超音波振動を付加する と, 溶接部の引張強さは向上し, 溶接速度が $3.33 \mathrm{~mm} / \mathrm{s}$ と $6.67 \mathrm{~mm} / \mathrm{s}$ の場合には約 $12 \%$ 向上した。

降伏強さや引張強さなどの材料の引張特性に対して, オーステナイト結晶粒の大きさ, サブグレインの大きさや

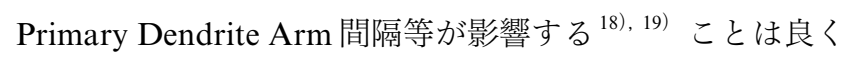
知られている。

溶接時に超音波振動を付加すると, Fig. 6 と Fig. 7 に示し 
たようにオーステナイト結晶の幅が減少すること，また， Fig. 8 と Fig. 9に見られるようにセルラーデンドライトはセ ル化してサブグレインになること, さらに, Fig. 12 に示し たように Primary Dendrite Arm 中心の間隔が減少した。つ まり, 凝固組織の緻密化が生じており, これによって溶接 部の引張強さが向上したと考えられる。

\section{5. 溶接部の引張強さに及ぼす超音波振動振幅の影響}

これまでは, 超音波振動振幅が $5.0 \mu \mathrm{m}$ の場合について, その影響を調べてきた。つぎに, 振動振幅を $5.0 \mu \mathrm{m}$ に加え, $2.1 \mu \mathrm{m}, 4.3 \mu \mathrm{m}, 5.3 \mu \mathrm{m}$ 打よび $7.5 \mu \mathrm{m}$ と変化させてその 影響を調べた。溶接速度は $3.33 \mathrm{~mm} / \mathrm{s}$ に限定した。

Fig. 13に振動振幅を変化させたときの溶接部の引張強さ を示す．振動振幅の増加とともに引張強さが大きくなる傾 向にある。この場合も, 前章までに示してきたようにオー ステナイト結晶幅の減少や凝固組織の変化に起因している と思われるので, この点について調べた．

溶接金属部のオーステナイト結晶幅の変化はFig. 14に示 すようであり，振幅の増加とともに小さくなった。

溶接金属部のセルラーデンドライトは Fig. 9 に示すよう なサブグレインになっており, サブグレイン間の結晶方位 差はFig. 15に示すように, 振幅の増加とともに大きくなっ

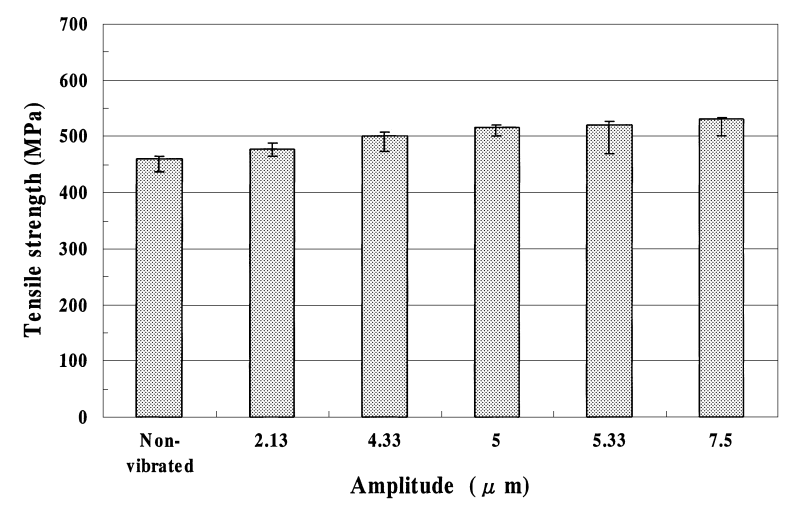

Fig. 13 Relation between tensile strength of the weld and the ultrasonic vibration amplitude.

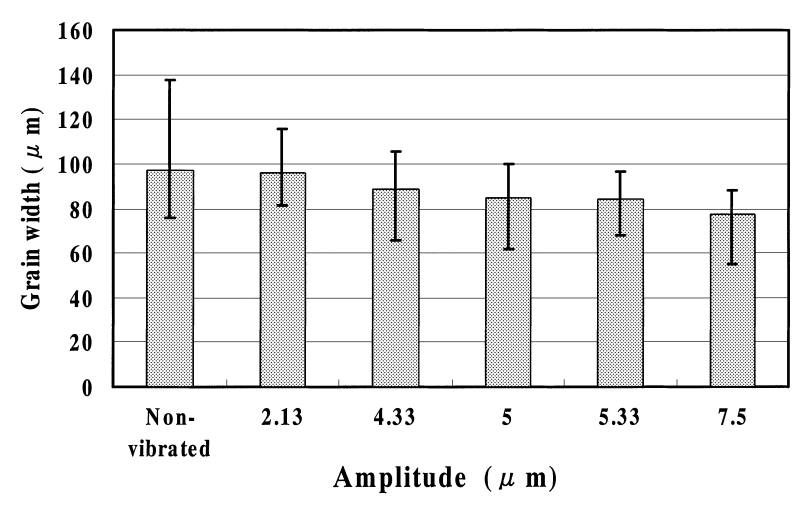

Fig. 14 Relation between columnar grain width in the weld metal and ultrasonic vibration amplitude.

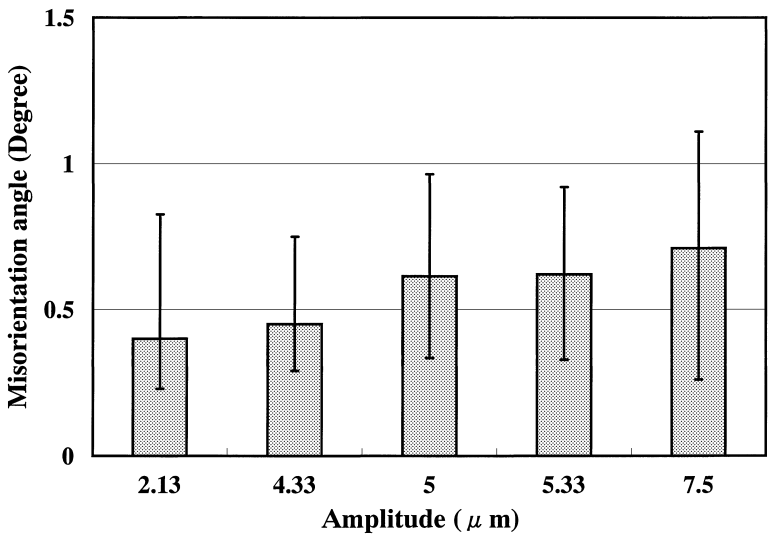

Fig. 15 The effect of ultrasonic vibration amplitude on the misorientation angle of subgrains in weld metal.

た.また, Primary Dendrite Arm 中心間距離も振動振幅の 増加とともに小さくなった.

このように, 超音波振動振幅の増加とともにオーステナ イト結晶の幅が小さくなること, 成長方向に平行方向の Primary Dendrite Arm 中心間距離も小さくなることが, 振 動振幅の増加とともに溶接部の引張強さが向上した要因と 考えられる。.さらに，成長方向に隣接するサブグレイン間 の方位差が若干大きくなることも一因と考えられるが，判 然としない.

\section{6. 結言}

本研究では, 溶接中に超音波振動を与えることによって 溶接金属組織を緻密化し, 溶接部の機械的性質を向上させ ることが可能か否かを明らかにすることを目的に行った. すなわち，オーステナイトステンレス鋼板に超音波振動を 与えながらティグによるビードオンプレート溶接を行い, 溶接部の機械的性質や溶接金属の凝固組織におよぼす超音 波振動の影響について検討した。得られた結論は大要次の ようである。

1）超音波振動を付加することによって, 溶接部の引張強 さは超音波振動を付加しない場合よりも向上する.

2）超音波振動を付加することによって，溶接金属部の オーステナイト柱状結晶幅が減少し，オーステナイト結 晶粒が小さくなることが溶接部の引張強さが向上する一 因と考えられる。

3）超音波振動を付加しない時に形成される溶接金属部の セルラーデンドライトは, 超音波振動を付加することに よって，成長方向に連なったサブグレインになる。サブ 粒界の形成も溶接部の引張強さを向上させると考えられ る.

4）超音波振動を付加することによって，溶接金属部の Primary Dendrite Arm の中心間距離は小さくなる.これ によっても溶接部の引張強さが向上すると考えられる.

5）上記の現象は, 超音波振動の振幅を増加させるとより 
顕著になる。

\section{参 考 文 献}

1) Japan Welding Society: 溶接 - 接合便覧, Maruzen (1990), 42. (in Japanese)

2) J. Cambel: Grain refinement of solidifying metals by vibration: a review, Int. Met. Rev., 26-2 (1981), 61-64

3) O.V. Abramov: Action of high intensity ultrasound on solidifying metal, Ultrasonics 25-3 (1987), 73-82

4) C. Vives: Crystallization of aluminum alloys in the presence of cavitation phenomena induced by a vibrating electromagnetic pressure, J. of Crystal Growth, 158-1 (1996), 118-127

5) Y. Osawa, G. Aragane, S. Takamori, A. Sato and O. Ohashi: Effects of Ultrasonic Vibration on Refining of Crystal Structures of Al-Si Alloys During Solidification, Chuzokougaku, 71-2 (1999), 98-103. (in Japanese)

6) Y. Osawa: Study on Development of Fine-grain Structure Materials by means of Ultrasonic Vibration, Doctoral Thesis (2000). (in Japanese)

7) Y. Kanamori, T. Ieki, K. Ozaki and K. Kobayashi: Grain Refinement of Casting Structure of Magnesium Alloy, Report of Mie Prefectural Research Institute, 24 (2000), 143-146. (in Japanese)

8) F. Matsuda, H. Nakagawa, K. Nakata and T. Ayani: Effect of Electromagnetic Stirring on Weld Solidification Structure of Aluminum Alloys, J. of Light Metal Welding, 16-1 (1978), 820. (in Japanaese)

9) S. Mukae, M. Katoh, K. Nishio and T. Tsutsui: Effect of Electromagnetic Stirring on Weld Solidification Structure of 5052
Alloy, J. of Light Metal Welding, 22-7 (1984), 299-309. (in Japanaese)

10) T. Watanabe, H. Nakamura and K. Ei: Solidification Control of Austenitic Stainless Steel Weld Metal by Electromagnetic Stirring, Trans. of JWS, 21-2 (1990), 37-42

11) T. Watanabe and S. Shibata: The relation of grain boundary behavior in the heat-affected zone to the weld metal grain boundary growth of austenitic stainless steel, Quar. J. JWS, 13-2 (1995), 262-269. (in Japanese)

12) F. Matsuda: 溶接治金学, Nikkan Kogyo Shinbunsha(1972), 119-137. (in Japanese)

13) H. Gotoh and T. Watanabe: Grain Growth Direction and Fracture Path of Austenitic Stainless Steel Multi-Pass Weld Metal, J. High Temp. Soc., 24-1 (1998), 29-35. (in Japanese)

14）K. Monma: 鉄鋼材料学, Jikkyo publisher (1981), 87. (in Japanese)

15) T. Shibayanagi and S. Hori: Analysis of grain orientation by ECP method, J. of Light Met., 42-5 (1992), 306-315. (in Japanese)

16) V. Randle and B. Ralph: A practical approach to the determination of the crystallography of grain boundaries, J. of Mat. Sci., 21 (1986), 3823-3828

17) W.T. Read and W. Shockley: Dislocation Models of Crystal Grain Boundaries, Phys. Rev., 78-3 (1950), 275-289

18) K. Minoda and H. Nagaoka: Effect of Heat Input on Mechanical Properties of 5083-O Welds under High Current MIG Process, J. JWS, 45-1 (1976), 51-58. (in Japanese)

19) T. Yamguchi, M. Kato, K. Nishio and K. Fukami: Hardness Distribution of Aluminum alloy A5052 Welded with YAG Laser, Quar. J. JWS, 19-1（2001）, 114-121.（in Japanese） 